Журнал «Герспективитаінноваціїнауки»

(Серія «Гедагогіка», Серія «Гиихологія»), Серія«Медицина»

№5(5) 2021

УДК 811.111'276.6:004.738.5

https://doi.org/10.52058/2786-4952-2021-5(5)-678-687

Шандра Наталія Андріївна кандидат педагогічних наук, доцент кафедри іноземних мов для природничих факультетів факультету іноземних мов, Львівський національний університет імені Івана Франка, вул. Університетська, 1, м. Львів, 79000, тел.: (032) 239-44-54, e-mail: nataliya.shandra@lnu.edu.ua, https://orcid.org/0000-0003-1321-4828

Токарсва Ольга Вікторівна кандидат педагогічних наук, асистент кафедри англійської мови 3 підготовки морських фахівців за скороченою програмою Херсонської державної морської академії, Проспект Ушакова, 20, м. Херсон, e-mail: otokareva261276@gmail.com, https://orcid.org/0000-0001-9566-0017

Петрова Анастасія Іванівна кандидат педагогічних наук, старший викладач кафедри методики навчання іноземних мов Вінницького державного педагогічного університету імені Михайла Коцюбинського, вул. Острозького, 32, м. Вінниця, 21000, тел.: (098) 279-20-61, e-mail: nastyapetroff@ukr.net, https://orcid.org/ 0000-0003-4323-3018

\title{
РОЗВИТОК КРИТИЧНОГО МИСЛЕННЯ КРІЗЬ ПРИЗМУ ТАКСОНОМЇ̈ БЛУМА НА ЗАНЯТТЯХ УДОСКОНАЛЕННЯ НАВИЧОК ЧИТАННЯ ІНОЗЕМНОЮ МОВОЮ
}

Анотація. У статті подано визначення поняття «критичне мислення» як рефлективного мислення, активного, наполегливого та уважного обдумування міркувань чи знань на основі даних, які їх підтримують та виведення подальших висновків. Подано трактування даного поняття Бенджаміном Блумом, який визначив «критичне мислення» як здатність отримувати знання крізь вивчення ідей у контексті таких шести рівнів: знання, розуміння, застосування, аналіз, синтез та оцінювання.

Здійснено огляд наукової літератури щодо трактування поняття «критичне мислення» та «таксономія» як науку про принципи та способи класифікації й номенклатури складноорганізованих ієрархічних систем дійсності: органічного світу, об'єктів географії, геології, мовознавства, суспільства тощо.

Акцентується увага на тому, що під час навчання у закладах вищої освіти студенти повинні виконувати розумові дії різних рівнів: порівнювати, аналізувати, узагальнювати, аргументувати, оцінювати, створювати нове тощо.

Детально описано та проаналізовано шість рівнів таксономії Блума, поділених на нижчий та вищий рівні. Наголошено, що до розумових вмінь низького рівня Б. Блум відносить такі когнітивні процеси, як знання, розуміння та застосування. До розумових вмінь високого порядку відносяться такі 
процеси, як аналіз, синтез та оцінка. Зазначено, що у порівнянні 3 іншими комунікативними навичками, такими як читання чи письмо, критичне мислення не $є$ вродженим вмінням, а повинне бути розвиненим під керівництвом такої обізнаної людини, як викладач.

Вказано, що викладачам закладів вищої освіти надзвичайно важливо інтегрувати критичне мислення у процес навчання іноземних мов, оскільки саме викладач $є$ рушійною силою зміни навчальної поведінки студентів. Застосування таксономії Блума на заняттях з іноземної мови покращує зміст навчання та мовну компетентність студентів.

Також подано авторську п’ятирівневу модель розвитку критичного мислення на заняттях удосконалення навичок читання іноземною мовою, яка складається 3 наступних етапів: ознайомлення студентів 3 базовими та культурними знаннями; пояснення головної думки кожного окремого абзацу; аналіз логічної побудови тексту; оцінювання логічної побудови тексту та виконання письмового завдання на основі прочитаного.

Ключові слова: критичне мислення, таксономія Блума, іноземна мова, навички читання.

Shandra Nataliya Andriivna Candidate of Pedagogical Sciences, Associate Professor of the Department of Foreign Languages for Sciences at the Faculty of Foreign Languages, Ivan Franko National University of Lviv, Universytetska St., 1, Lviv, 79000, tel.: (032) 239-44-54, e-mail: nataliya.shandra@ Inu.edu.ua, https://orcid.org/0000-0003-1321-4828

Tokarieva Olha Viktorivna Candidate of Pedagogical Sciences, Assistant of the Department of English Language for Maritime Officers (abridged programme), Kherson State Maritime Academy, Ushakov Ave., 20, Kherson, e-mail: otokareva261276@gmail.com, https://orcid.org/0000-0001-9566-0017

Petrova Anastasiia Ivanivna Candidate of Pedagogical Sciences, Senior lecturer of the Department of Methods of Foreign Language Teaching, Vinnytsia Mykhailo Kotsiubynsky State Pedagogical University, Ostrozkogo St., 32, Vinnytsia, 21000, tel.: (098) 279-20-61, e-mail: nastyapetroff@ukr.net, https://orcid.org/ 00000003-4323-3018.

\section{DEVELOPMENT OF CRITICAL THINKING TROUGH BLOOM'S TAXONOMY TO IMPROVE FOREIGN LANGUAGE READING SKILLS}

Abstract. The article defines the concept "critical thinking" as reflective thinking, active, persistent and attentive reflection on reasoning or knowledge based on the data that support them and making further conclusions. Benjamin Bloom's interpretation of this concept is presented, who defined "critical thinking" as the ability to acquire knowledge through the study of ideas on the context of the 
following six levels: knowledge, understanding, application, analysis, synthesis and evaluation.

A review of the scientific literature on the interpretation of "critical thinking" and "taxonomy" as a science of principles and methods of classification and nomenclature of complex hierarchical systems of reality: the organic world, objects of geography, geology, linguistics, society, has been conducted.

Emphasis is placed on the fact that while studying in higher education institutions, students must perform mental activities of different levels: compare, analyze, summarize, argue, evaluate, create etc.

Six levels of Bloom's taxonomy, divided into lower and higher levels, are described in details. It is stressed that Bloom indicated such mental skills as knowledge, understanding and application as being low-level cognitive processes. Whereas such skills as analysis, synthesis and evaluation are defined to be high-level mental processes. It is noted that compared to other communication skills, such as reading or writing, critical thinking is not an innate one but should be developed under the guidance of an informed person like a teacher.

It is pointed out that it is significant for university teachers to integrate critical thinking into the process of learning foreign languages since a teacher is a driving force behind students' learning behavior. The use of Bloom's taxonomy in foreign language classes improves the content of learning and language competence of students.

The authors' five-level model of developing critical thinking in the classes of improving foreign language reading skills is also presented. The mentioned model consists of the following stages: acquainting students with background and cultural knowledge; explanation of the main idea of each paragraph; analysis of logical construction of the text and implementation of a written task based on covered material. skills.

Keywords: critical thinking, Bloom's taxonomy, foreign language, reading

Постановка проблеми. За сучасних мінливих умов інформаційного суспільства студентам потрібна не готова інформація, а вони радше вимагають методів i найкращих можливих способів отримання, осмислення та застосування власних знань. В освітній сфері це зумовлює підвищений інтерес 3 боку викладачів як до проблеми становлення, так й розвитку критичного мислення загалом і на заняття 3 іноземної мови в контексті удосконалення навичок читання, зокрема.

Аналіз останніх досліджень і публікацій. Поняття «критичне мислення» зазнавало уточнень та доповнень 3 часу своєї появи 2500 років тому. Проводячи екскурс у наукову літературу, варто зазначити різнобічне трактування даного поняття різними вченими. Першим визначення «критичному мисленню» запропонував Джон Дьюї [1], який описав якого як рефлективне мислення, активне, наполегливе та уважне обдумування 
міркувань чи знань на основі даних, які їх підтримують та виведення подальших висновків [1, с. 99-116]. Окрім того, науковець запропонував 5ти фазну модель критичного мислення, яка охоплює: припущення, визначення проблеми, окреслення гіпотези, аргументацію та тестування гіпотези. Дж. Дьюї наголошує на необхідності активної та наполегливої участі кожної особи у власному процесі обмірковування, надаючи причини та обгрунтування й оцінювання висновків. Таким чином, навчання удосконалює процес рефлективного мислення [2, с. 136].

Бенджамін Блум визначив «критичне мислення» як здатність отримувати знання крізь вивчення ідей у контексті таких шести рівнів: знання, розуміння, застосування, аналіз, синтез та оцінювання. Знання та розуміння було віднесено до розумових навичок нижчого рівня, всі інші елементи - до вищого рівня [3]. Три вищі рівня, які охоплюють аналіз, синтез та оцінювання, репрезентують критичне мислення [4, с. 8]. В освітньому просторі таксономію Блума розглядають як класифікацію різних цілей, які викладачі ставлять своїм студентам [5].

Мета статті - охарактеризувати таксономію Блума та на ii основі запропонувати авторську п'ятирівневу модель розвитку критичного мислення на заняттях удосконалення навичок читання іноземною мовою.

Виклад основного матеріалу. Таксономія (3 давньогрецької мови «taxis» - упорядкування та «nomos» - закон або наука) - наука про принципи та способи класифікації й номенклатури складноорганізованих ієрархічних систем дійсності: органічного світу, об’єктів географії, геології, мовознавства, суспільства тощо. Під час навчання у закладах вищої освіти студенти повинні виконувати розумові дії різних рівнів: порівнювати, аналізувати, узагальнювати, аргументувати, оцінювати, створювати нове тощо. Бенджамін Блум розташував перелік когнітивних процесів низького та високого рівнів в ієрархічній послідовності від простого до складного, створивши таким чином таксономію. До розумових вмінь низького рівня Б. Блум відносить такі когнітивні процеси, як знання, розуміння та застосування. До розумових вмінь високого порядку відносяться такі процеси, як аналіз, синтез та оцінка [3].

У порівнянні з іншими комунікативними навичками, такими як читання чи письмо, критичне мислення не $є$ вродженим вмінням, а повинне бути розвиненим під керівництвом такої обізнаної людини, як викладач. На думку Д. Таннера, критичне мислення не $є$ інстинктивним, оскільки його потрібно розвивати шляхом зовнішньої мотивації. Викладачі відіграють ключову роль у формуванні критичного мислення [6, с. 92].

На нашу дамку, викладачам закладів вищої освіти надзвичайно важливо інтегрувати критичне мислення у процес навчання іноземних мов, оскільки саме викладач $є$ рушійною силою зміни навчальної поведінки студентів. Застосування таксономії Блумаа на заняттях з іноземної мови покращує зміст навчання та мовну компетентність студентів. Ми переконані, що між викладанням іноземної мови та таксономією Блума існує тісний зв'язок. 
Журнал«Герспективита іновації наукиљ

(Серія «Гедагогіка», Серія«Гடихологія», Серія«Медицина»

№5(5) 2021

Таксономія Блума охоплює когнітивну сферу та складається із шести наступних рівнів, зазначених від нижчого до найвищого (Рис. 1, Рис. 2):

1) знання: конкретний матеріал, термінологія, факти, визначення, критерії;

2) розуміння: пояснення, інтерпретація;

3) застосування: застосування абстрактних понять, загальних принципів чи методів до конкретних ситуацій;

4) аналіз: поділ складної проблеми на її складові та розуміння організації й зв'язку між частинами; усвідомлення відмінностей між гіпотезою і фактом, а також між доречними та недоречними факторами;

5) синтез: креативне розумове поєднання ідей та понять з різних ресурсів для формування складних ідей у нову, інтегровану та значущу ідею, підпорядковану відповідним обмеженням;

6) оцінювання: здійснення суджень щодо ідей і методів, використовуючи зовнішні докази [7].

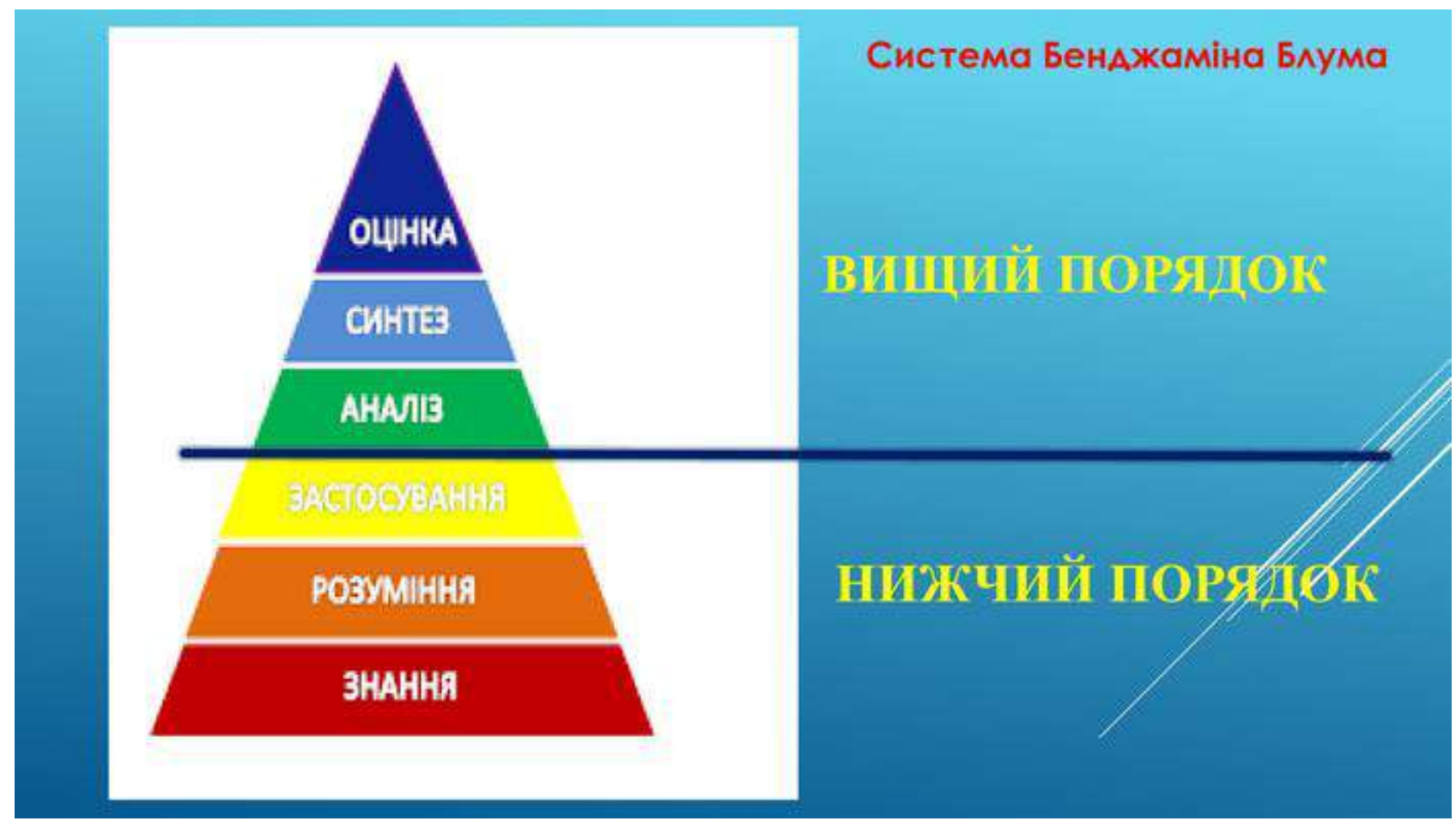

Puc. 1

Рівень оцінювання, на якому відбувається розвиток критичного мислення, охоплює такі категорії:

$\checkmark$ оцінювання основане на внутрішніх знаннях i переконаннях (пояснення, логічні умовиводи, конструктивність);

$\checkmark$ оцінювання основане на зовнішніх критеріях (стандарти, правила, норми) [8, с. 113]. 

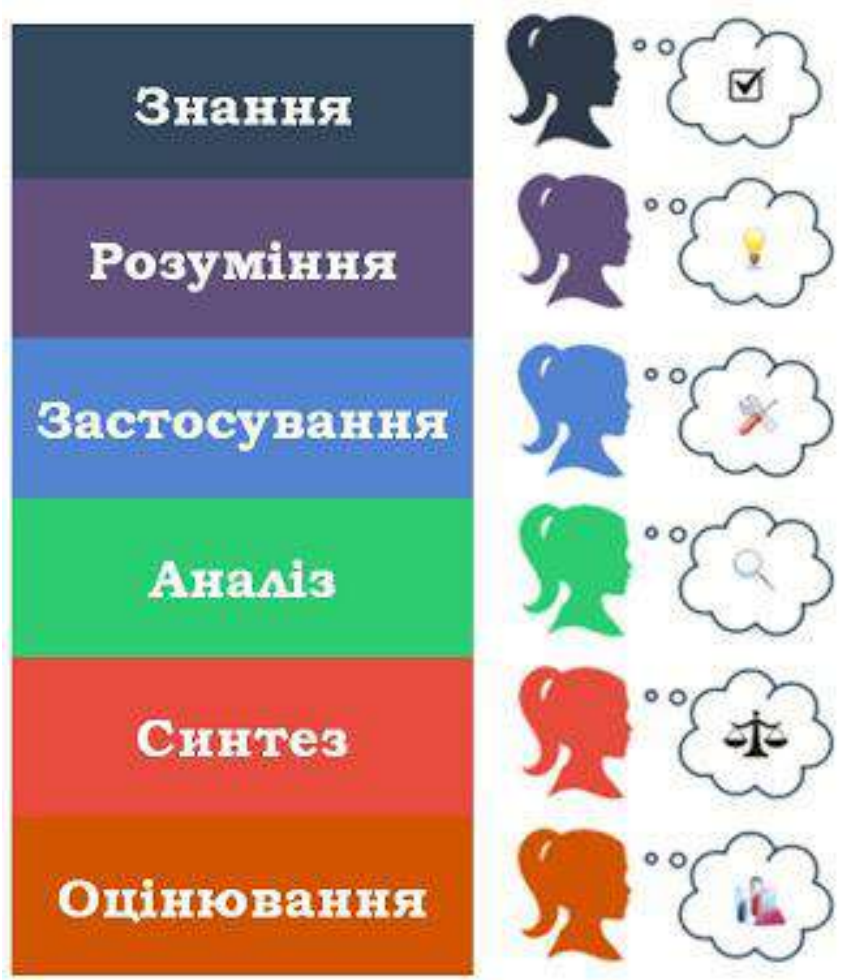

запам'ятовування та відтворсння матеріалу, який

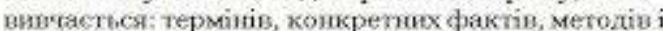

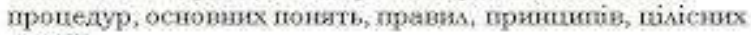
теорій

здатність мюдиви встановмонати зВязок одного матеріалу 3 іншим, перетворювати його із отноі форми вираженнн В іншу, переводити його 3 одніеї кмовн на іншу: Зі сАовесвоі у графінпу, математину і навгаки; пояснення, короткий викмад, прогнозування майбутніх наслідків, по. витинвакоть із наявних дантх

уміння викорнстовувати вивчений матеріал у конкретних умовах і нових снтуаніях: зестосунання прави, методів, уміння розбивати матеріал на скљадові понятв, законів, прингитів, теорій

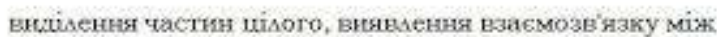
ними, осмислення принципів ортанізагіі цілого:учень. бачить помицки й огріхи в могіці міркувань, бачить

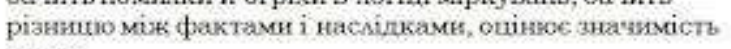
данатх

вміни комбінувати ехементи, шоб одержати иілез вовою системною властивістю: повідомиеннғ, пиан дій, нова схема тощо

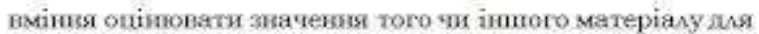
конкретної метн: учень опінюе могіку побудовим матеріалу у витмді пшсьмового тексту, опінюе відповідність внсновків ужеданим і $x . д$

Puc. 2

Погоджуємося 3 твердженням, що оцінка пов'язана із здатністю студента судити про цінність матеріалу, призначеного для певної мети. Цілком очевидно, що судження мають грунтуватися на певних критеріях. Як справедливо зазначав сам автор таксономії, результати навчання на даному рівні перебувають на найвищому щаблі когнітивної ієрархії, оскільки вони об'єднують елементи знання, розуміння, застосування, аналізу та синтезу, маючи здатність оцінювати, наказувати, робити висновки, критикувати та обгрунтовувати отримані результати [3].

Критичне мислення, яке за твердженням науковців [9], є здатністю інтегрувати факти, застосовувати узагальнення та розпізнавати помилки, вимагає від студентів використовувати зміст знань, з якими вони мають справу для кращого розуміння того, чого вони ще не знають. Воно також охоплює зусилля, спрямовані на пошук додаткової інформації, яка вимагає від студентів задавати питання і знайти відповіді на ці питання [10].

Критичне мислення на заняттях 3 іноземної мови можна викладати 3 метою удосконалення не лише навичок умовиведення, але й комунікативної компетентності студентів. Розвиток критичного мислення в межах вивчення іноземної мови спрямований на інтегрування мислення вищого порядку в процесі вивчення та володіння іноземною мовою, яке може надати глибше знання та усвідомлення мови, а, отже, принести практичну користь студентам [11, с. 85].

Під час традиційного заняття читання іноземною мовою студенти, в основному, навчаються покращувати свої мовні навички - спочатку для розширення словникового запасу, а потім для покращення здатності розуміти 
прочитане. Очікується, що вони отримають інформацію чи знання з тексту і сприймуть ідеї чи точки зору, викладені в письмовій формі. Погоджуємося 3 твердженням, що студентів варто навчити бути критичними читачами, які можуть запитати, упорядкувати, інтерпретувати, синтезувати та проаналізувати прочитане [2, с. 139].

На нашу думку, навчальний матеріал обраний для читання повинен викликати інтерес та мотивацію студентів, створюючи виклик їхньому мисленню. Науковець Піроззі [12, с. 325 ] слушно визначив критичне читання як розуміння письмового матеріалу високого рівня, яке потребує інтерпретації та навички оцінювання, а також вихід за межі явно зазначеного, заповнення інформаційних прогалин та прихід до логічних висновків. Таким чином критичне читання, зокрема й іноземною мовою, наголошує на активній ролі читання, оскільки читачі не просто отримують факти та знання в тексті, а й намагаються сформувати власну думку та погляди на те, що вони читають. У викладанні мови, відповідно до Уоллеса, критичний означає готовність задавати питання і міркувати про значення та використання мови [2, с. 139]. Заняття з читання повинні готувати критично налаштованих читачів, оскільки вони задають питання, систематизують, інтерпретують та аналізують прочитане [13, с. 491].

На основі дослідженого матеріалу та викладацької практики, ми пропонуємо впровадження п'ятирівневої моделі розвитку критичного мислення на заняттях удосконалення навичок читання іноземною мовою.

Перший рівень передбачає ознайомлення студентів 3 базовими та культурними знаннями. Він базується на переконанні, що знання культури нації, мова якої вивчається, $\epsilon$ важливішим від розуміння граматики прочитаного [2, с. 139]. На цьому етапі відбувається активізація знань студентів з певної теми. Перед прочитанням всього тексту, студенти читають лише заголовок, перший та останній абзаци. Потім відбувається обговорення прочитаного, під час якого студенти обмінюються своїми попередніми знаннями щодо даної теми та намагаються передбачити про що йтиметься в тексті. Таким чином збільшується зацікавлення даною метою, посилюється бажання прочитати цілий текст та удосконалюються навички передбачення на основі прочитаного матеріалу іноземною мовою.

На другому етапі відбувається пояснення головної думки кожного окремого абзацу. Розуміння слів, виразів та цілих речень $\epsilon$ важливим елементом опанування іноземною мовою. Саме тому, на нашу думку, на занятті читання з розвитку навичок критичного мислення потрібно заохочувати студентів визначати значення невідомого слова чи фрази шляхом здогадки та контексту. На даному рівні завдання викладача полягає у заохоченні студентів висвітлювати основну думку кожного абзацу на основі власного осмислення змісту прочитаного.

Третій рівень передбачає аналіз логічної побудови тексту. На цьому етапі вважаємо за доцільне використовувати методику «Елементи думки», 
запропоновану дослідником Паулом [14, с. 10]. Відповідно до даної методики, завдання викладача полягає у заохоченні студентів задавати наступні питання:

$\checkmark$ На яке ключове питання намагається відповісти автор?

$\checkmark$ Якою $є$ основна мета автора?

$\checkmark$ Якою є точка зору автора щодо даної теми?

$\checkmark \quad$ Які припущення висловлює автор у своїх міркуваннях?

$\checkmark$ Які наслідки аргументації автора?

$\checkmark$ Яку інформацію використовує автор, міркуючи над цим питанням?

$\checkmark \quad$ Які найважливіші висновки зроблені у тексті?

$\checkmark \quad$ Які основні концепції автора?

На четвертому етапі відбувається оцінювання логічної побудови тексту. Оскільки оцінювання $є$ однією із основних навичок критичного мислення, оцінка логічності тексту допомагає удосконалити не лише вміння читати іноземною мовою, а й мислення. На цьому етапі пропонуємо застосовувати «Інтелектуальні стандарти» Пауля [14, с. 11]. Нижчеподані запитання допоможуть оцінити логічну побудову тексту:

$>$ Чи чітко автор висловлюе свою точку зору, чи текст заплутаний та незрозумілий?

$>\quad$ Чи достатньо точно зазначені автором деталі та конкретні елементи, коли вони є важливими?

$>\quad$ Чи вводить автор у текст невідповідний матеріал, тим самим відхиляючись від своєї мети?

$>$ Чи автор залучає своїх читачів до розуміння важливих складних елементів даної теми, чи текст є поверхневим?

$>\quad$ Чи розглядає автор інші відповідні точки зору, чи текст $є$ занадто вузькоспрямованим?

$>$ Чи $є$ текст внутрішньо послідовним, чи містить непояснені протиріччя?

$>\quad$ Чи $є$ текст значущим, чи його тема є надто тривіальною?

$>$ Чи проявляє автор справедливість, чи використовує однобічний та вузький підхід?

Відповідаючи на запитання на третьому та четвертому етапах, вважаємо за доцільне використовувати такі методи навчання, як робота в парах, обговорення в групах та спільне навчання. Як справедливо зазначено науковцями, спільне навчання посилює процеси мислення. Завдяки такому навчанню студенти обмінюються своїми думками i, таким чином, застосовують інтерактивний підхід до вивчення іноземної мови. Ключовим компонентом спільного навчання є рефлексія членів групи [2, с. 140].

I завершальним рівнем розвитку критичного мислення на заняттях удосконалення навичок читання іноземною мовою є письмове завдання. На цьому етапі, після розуміння та оцінки тексту, студенти повинні написати резюме прочитаного, коментарі, подібні твори або створити власні аргументи 
схожого стилю. На даному рівні тренується вищий рівень навичок мислення синтез і застосування. 3 точки зору теорії викладання іноземних мов, навички читання найкраще розвиваються разом 3 письмом, аудіюванням та говорінням [15].

Висновки. Підсумовуючи, варто зазначити, що таксономія Блума викликає новий сплеск дослідницького інтересу, оскільки ï можна розглядати як фундаментальне поняття в сучасній теорії освіти та особливо у сфері навчання та розвитку навичок критичного читання іноземною мовою.

Для сприяння вивченню іноземної мови викладач повинен сприяти розвитку мислення вищого рівня - критичного. Саме 3 цією метою було запропоновано п'ятирівневу модель розвитку критичного мислення на заняттях удосконалення навичок читання іноземною мовою. У запропонованій моделі перший і другий рівні спрямовані на інтерпретацію тексту, третій і четвертий етапи зосереджуються на оцінці тексту, а п'ятий - на реакції читача. На наше переконання, дана модель $\epsilon$ практичною та ефективною для розвитку критичного мислення на заняттях удосконалення навичок читання іноземною мовою.

\section{Jimepamypa:}

1. Dewey, J. How We Think: A Restatement of the Relation Reflective Thinking to the Educative Process. Boston: Health.

2. Xu J. The Application of Critical Thinking in Teaching English Reading. Theory and Practice in Language Studies, 1(2), pp. 136-141, February 2011.

3. Bloom B. S. (1956). Taxonomy of Educational Objectives. Handbook I: The Cognitive Domain. New York: David McKay Co Inc.

4. Lai, E. R. (2011). Critical thinking: A literature review. Pearson's publications.

5. Orlich, D. C., Harder, R. J., Callahan, R. C., Trevisan, M. S., \& Brown, A. H. (2004). Teaching strategies: A guide to effective instruction. Belmont, CA: Wadsworth Cengage Learning.

6. Niazi S., Lodhi F. A., Mahmood H. A Critical Study about the Effects of Bloom's Taxonomy in the Context of English Language Teaching at University Level. PJER, 4(22), 2021, pp. 86-106.

7. Anderson, L., Krathwohl, D. (2001). A taxonomy for learning, teaching, and assessing. New York: Longman.

8. Korzh O. Bloom's Taxonomy and Its Role in Academic Writing and Reading Skills Training at English Classes. Science and Education, Issue 2, 2017, pp. 111-116.

9. D'Angelo, E (1970). The Teaching of Critical Thinking Through Literature, Elementary English, 47(5), 633-637.

10. Elias, M. J. (2014). The importance of asking questions to promote higher-order competencies. https://www.edutopia.org/blog/importance-asking-questions-promote-higher-ordercompetencies-maurice-elias.

11. Sanavi R. V., Tarighat S. Critical Thinking and Speaking Proficiency: A Mixed-method Study. Theory and Practice in Language Studies 4(1), January 2014, pp. 79-87.

12. Pirozzi, R. (2003). Critical Reading, Critical Thinking. New York: Longman.

13. Paul, Richard. (1995). Critical Thinking: How to Prepare Students for a Rapidly Changing World. CA: Foundation for Critical Thinking.

14. Paul, R. \& Elder, L. (2001, 2008).The miniature guide to critical thinking: Concepts and tools. Dillon Beach, CA: Foundation for Critical Thinking--How to read a paragraph Dillon Beach, CA: Foundation for Critical Thinking. 
15. Anderson, L. W., \& Krathwohl, D. R. (2001). (Eds.). A taxonomy for learning, teaching and assessing: A revision of Bloom's Taxonomy of educational objectives: Complete edition. New York: Longman.

\section{References:}

1. Dewey, J. How We Think: A Restatement of the Relation Reflective Thinking to the Educative Process. Boston: Health.

2. Xu J. The Application of Critical Thinking in Teaching English Reading. Theory and Practice in Language Studies, 1(2), pp. 136-141, February 2011.

3. Bloom B. S. (1956). Taxonomy of Educational Objectives. Handbook I: The Cognitive Domain. New York: David McKay Co Inc.

4. Lai, E. R. (2011). Critical thinking: A literature review. Pearson's publications.

5. Orlich, D. C., Harder, R. J., Callahan, R. C., Trevisan, M. S., \& Brown, A. H. (2004). Teaching strategies: A guide to effective instruction. Belmont, CA: Wadsworth Cengage Learning.

6. Niazi S., Lodhi F. A., Mahmood H. A Critical Study about the Effects of Bloom's Taxonomy in the Context of English Language Teaching at University Level. PJER, 4(22), 2021, pp. 86-106.

7. Anderson, L., Krathwohl, D. (2001). A taxonomy for learning, teaching, and assessing. New York: Longman.

8. Korzh O. Bloom's Taxonomy and Its Role in Academic Writing and Reading Skills Training at English Classes. Science and Education, Issue 2, 2017, pp. 111-116.

9. D'Angelo, E (1970). The Teaching of Critical Thinking Through Literature, Elementary English, 47(5), 633-637.

10. Elias, M. J. (2014). The importance of asking questions to promote higher-order competencies. https://www.edutopia.org/blog/importance-asking-questions-promote-higher-ordercompetencies-maurice-elias.

11. Sanavi R. V., Tarighat S. Critical Thinking and Speaking Proficiency: A Mixed-method Study. Theory and Practice in Language Studies 4(1), January 2014, pp. 79-87.

12. Pirozzi, R. (2003). Critical Reading, Critical Thinking. New York: Longman.

13. Paul, Richard. (1995). Critical Thinking: How to Prepare Students for a Rapidly Changing World. CA: Foundation for Critical Thinking.

14. Paul, R. \& Elder, L. (2001, 2008).The miniature guide to critical thinking: Concepts and tools. Dillon Beach, CA: Foundation for Critical Thinking--How to read a paragraph Dillon Beach, CA: Foundation for Critical Thinking.

15. Anderson, L. W., \& Krathwohl, D. R. (2001). (Eds.). A taxonomy for learning, teaching and assessing: A revision of Bloom's Taxonomy of educational objectives: Complete edition. New York: Longman. 